\title{
The Principal's Leadership in Shaping the Character of Indonesia's Golden Generation: A Literature Review
}

\author{
Margi Jayanti ${ }^{1}$, Hasan Hariri ${ }^{2}$, Dedy Hermanto Karwan ${ }^{3}$ \\ \{margi.jayanti@gmail.com ${ }^{1}$, hasan.hariri@staff.unila.ac.id ${ }^{2}$,dedy.karwan@fkip.unila.ac.id ${ }^{3}$ \} \\ Magister of Educational Administration, Universitas Lampung, Indonesia ${ }^{1,2,3}$
}

\begin{abstract}
Character education takes an important part in preparing for Indonesia's golden generation. To realize a good character education, school needs an effective leader who is able to prepare a golden generation to help Indonesia to be a better nation and be ready to compete in global competition. The importance of the principal's leadership to design the character golden generation of Indonesia is very interesting to study, and this article aims to review how the principal's leadership in shaping the character of Indonesia's golden generation. There are a number of articles found about the principal's leadership review and their effect on the character of Indonesia's golden generation that was made not only by researchers in Indonesia but also written by foreign researchers. The purpose of this literature review is to find out the role of the principal's leadership in shaping the character of the golden generation of Indonesia. Based on the results of literature reviews from various countries in the world, we found the scope of the article was still limited, so, we wanted to know more deeply and was interested in following up on the discussion about the role of the principal's leadership in shaping the character of Indonesia's golden generation towards demographic bonus 2045.
\end{abstract}

Keywords: Character Education, Golden Generation, Principal's leadership

\section{Introduction}

Character education is one of the fundamental efforts in creating learning situations that are suitable for students' self-development and is designed to shape students' character. As an educational institution, the school has an important role to design the character of students. Because it is expected that through character education, students are expected to be closer to God, have strong faith, so they become virtuous, tolerant, have a motivation to fight for life, hard-working and discipline [1]. Build the skills and character are important efforts in preparing Indonesian youth to face global economic competition [2].

Besides, with character education, the identity of students will be well-formed, so that the nation's generation will have a good character. In shaping quality characters, coaching is needed from an early age. Tilaar stated that the term 'character' is the essential features of a person or a group or nation that is very prominent so that it can be recognized in various situations or is a trademark of someone. So, through character education, Indonesia's future 
generation will have intelligence in cognitive, affective, and psychomotor. This will strengthen the foundation of nationality towards a better nation [3].

In this context, there are two main roles of school, those are educating students with a variety of subjects, cognitive skills and knowledge, and educating students in individual and social development. Therefore, the school has a major role in character education as the social capital of students in their lives [4]. If the young generation of this nation is not educated with good character, then the nation's character -over time- will be destroyed, as stated by Thomas Lickona in Agus Wibowo's book entitled Character Education: Strategies to build the Character of Civilized Nations, he stated that: a nation is going to ruin when its character is pawned [5].

The principal is the person who has the highest authority in the school, because the principal is responsible for all school activities and plays an important role to improve the quality of education [6], [7]. Bush said that the Leader is the person who sets goals, provides innovations, and takes actions to his employees [8]. Principal's leadership is one of the factors that influence the quality of the school [9]. The principal's leadership is very important for the success of the school organization. Leaders can create positive changes in education by encouraging staff to take initiatives and change for effective and efficient school management [10], [11].

Principal's leadership influences students' potential in a variety of ways, through instructional and non-instructional assignments. The level and way of the leadership of a school principal influence student learning outcomes, but still depends on all aspects in the school environment, such as the principal, teachers, students, and the community [12].

The role of the principal is very important in transforming the educational process, performance, and student learning outcomes. Because the quality of school leaders is related to the student's result; therefore, schools must invest in training and upgrading the principal's leadership [13]. As a person who has the highest authority and rights in the school, the principal has seven tasks, those are: as an educator, as a manager, as an administrator, as a supervisor, as a leader, as an innovator, and as a motivator [14]. In short, Principals play a key role in this domain by design the school environment, motivating, and supporting learning in school [15].

The proper principal's leadership in shaping the character of the golden generation is very important. A demographic bonus must be welcomed. Demographic bonus is a situation where the number of productive age population is higher than the number of non-productive age population. It can be said that the principal's leadership has a large impact in shaping the golden generation character. The development of skills and character is one of the important efforts in preparing Indonesian youth to support the achievement of demographic bonuses and to face global economic competition [2]. Based on the description above, the authors feels the need to know more deeply about "What is the Role of the Principal's Leadership in Shaping Indonesia's Golden Generation Character?"

\section{Literature Review}

\subsection{Principal's Leadership}

Leadership according to Heifetz is a social activity [16]. The principal is the person who has the highest authority in the school, because the principal is responsible for all school 
activities and plays an important role in improving education's quality and support the academic success of students, especially the students who are marginalized because of race, ethnicity, language, ability, socioeconomic status, gender, and religion [17], [6], [7].

The principal has an important role in influencing; encourage; guide; directs; and mobilizing teachers, staff, students, parents, and other stakeholders to achieve the goals set. [18] . A significant effect of school leadership on all scholl elements, positively influences the quality of teaching and learning. The function of leadership is to design organizational conditions that foster high quality in teaching and produce improvements in learning outcomes [19].

Principal's leadership is crucial for the success of school organizations because leaders create positive changes in education by encouraging staff to take initiatives in changing towards progress [10]. The leadership of the principal influence students' potential in various ways, through both instructional and non-instructional tasks. The level and way of the leadership of the principal could influence student learning outcomes but still depends on all elements in the school, such as school principals, teachers, students, and the community [12]. The role of the principal is very important in transforming the educational process, performance, and student learning outcomes because the quality of school leaders is related to the academic success of students; therefore, a school must invest in training to upgrade the principal's leadership [13], [20]. In short, the principal plays a key role in this domain by shaping the school environment, motivating, and supporting in school [15]. Three types of principal leaders' profiles were identified: "principals who think about people", "principals who think administratively:" and "principals who think moderately" [21].

\subsection{Indonesia's Golden Generation Character}

The Golden Generation is the generation of Indonesian who are often described as superiors, choices, creative and have high integrity and exceptional intellectual space. Changes in the generation of dynamic pioneers towards the good to shape the life and culture of a better nation. Various concepts and programs for the formation of the Golden Generation must be born, even forming the grand design of the formation of the Indonesian Golden Generation in Indonesia. The development of Indonesia's young generation must be balanced between aspects of knowledge (cognitive), character (affective), and skills (psychomotor) [22]. Every human being has the potential to display a good character that is suitable for him the nature of human creation since he was born. However, there must be a long process of developing good character through care, education, and social activities. Family, School, and Community play a very important role in forming, developing, and educating good human characters [23].

Education is a process of cultural reciprocity between individuals and communities. One of the important roles of education is filtering foreign cultures in society and maintaining local culture. Besides, education also plays a role in developing academic skills, shaping character, and positive behavior. To be successful, character education requires the right method so that teachers must be able to integrate character education into everyday life. Besides, teachers must use appropriate learning methods so that students can easily understand them. In addition to integrated learning, character education can also be integrated through cross-curricular, cocurricular, and extracurricular activities. Character education can be implemented with school programs and activities [24].

Character is an integral part that must be built properly. So that the young generation as the hope of the nation who is responsible for determining the future, students must have the 
attitude and intelligence of strong and correct morality to build the nation [25]. Character education is not just about teaching right or wrong, but more than that besides this habit of internalizing (habituation) about which is good. Students will then know and understand good values or things that are true (cognitive), can feel values and norms (affective), and able to perform good behavior (psychomotor). Character education involves moral knowledge, moral feelings, and moral actions. So, character means values and norms that are related to national values and norms that are based on the Pancasila National Philosophy [23].

Character education in Indonesia is to develop and to familiarize the moral values and norms of Pancasila in our daily lives to have a peaceful and good life. The purpose of character education is to develop the character of the nation in Indonesia ordering that Indonesian people can carry out the values of Pancasila. The character of the educational function as (1) develops the basic potential of people to be kind, to have good thoughts, and to do good behavior; (2) strengthening and developing multicultural behavior, and to improve the cultural life of the nation which is competitive in Indonesia's world living relationships [23].

Characteristics of education are human activities in which educative and didactic actions are made for a growing generation. Ideally, education characteristics would be better implemented early. So, during the implementation of certain values, students will get educative actions. Through the education of school characteristics, this can encourage students to do, so with noble character values, such as respecting and caring for others, responsibilities, discipline, and many more values that need to be implemented [26].

The objectives of character education put forward by the Ministry of Education of the Republic of Indonesia are a). Developing the development of conscience / affective as human beings and citizens who uphold cultural values and national character, b). Developing a commendable attitude habit that is in line with universal values and religious and cultural traditions of the nation, c). To instill a spirit of leadership and responsibility as the next generation, d). Developing the abilities of students to become independent, creative, nationalistic people, and e). Develop a school environment that is safe, honest, full of creativity and a friendly learning environment, and has a high sense of nationality and is full of strength (dignity) [22].

Character is the values of human behavior related to God, self, people, environment, and nationality, which are manifested in thoughts, attitudes, feelings, words, and actions based on religious norms, law, manners, culture, and customs [27]. Character education is a teacher's effort to shape student character. Besides the term character, we also know the word moral. Based on the meaning of the word in the dictionary, there is no significant difference between character and morals. Character and morals are defined as actions that occur without thinking (spontaneously) because both morals and morals are embedded in the mind, in other words, they can be called habits. [28].

The application of the value of character education can be done through learning, that is by including character values in each lesson because in each learning not only requires cognitive aspects but also affective and psychomotor. In Presidential Regulation (PERPRES) number 28 of 2017, the president divides the values of character education into 18 parts. One of the 18 characters is 'hard work'. The character of hard work is persistence in trying to get the target, this character education is said to be important to improve the life of the nation in aim to fight for the ideals of the nation's generation to shape a good golden generation character [29]. If we look at the Purpose of National Education in UUSPN (Indonesian Law) No. 20 of 2003, the desired national character in national education is the character that aims at developing the potential of students to become people who believe in God, have good 
character, are healthy, knowledgeable, capable, creative, independent, and become citizens of a democratic and responsible [30]

In order for humans to have good character, character education is required since they are in school. Character education is a process of cultural internalization within a person and society to make humans and society have good morals. Thomas Lickona emphasizes the three components of good character: moral knowledge (moral knowledge), moral feeling (moral feeling), and moral action (moral action). The three parts of the character components have a relationship that is interrelated with one another. According to Lickona, good characters are: knowing good things, wanting good things, and doing good things. The character is expected to become a habit in thinking, a habit in the heart, and a habit in action [31]. The development of skills and character is one of the important efforts in preparing Indonesian youth in a global economic competition [2].

\section{Research Methodology}

This literature review focuses on the Principal's Leadership in Shaping the Character of the Indonesian Gold Generation. The authors conducted a study of this literature after determining the topic of writing and establishing the formulation of the problem, before plunging into the field to collect the necessary data. Data collection is done using Google scholar searching for articles and international and national journals with the keywords principal's leadership, character education, golden generation. The search ranged from 20152020 and total of 150 articles were identified.

The criteria for inclusion in this study are as follows:

a. Quantitative results from the principal's leadership in shaping the character of Indonesia golden generation .

b. This research is carried out in the world

c. This research uses English

d. Dissertations and theses are excluded

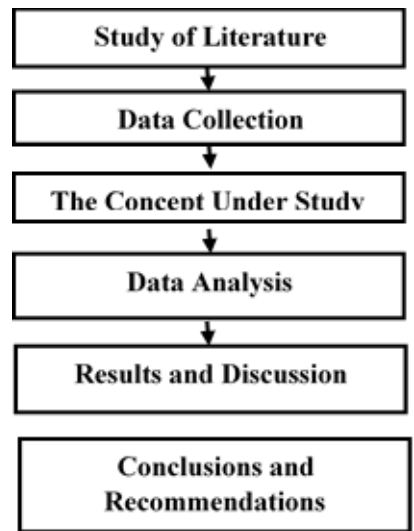

Fig 1. Flow of Literature Review 


\section{Results and Discussions}

\section{Table 1. The Principal's Leadership in Shaping the Character of Indonesia's Golden Generation}

\begin{tabular}{|c|c|c|c|c|c|}
\hline $\begin{array}{c}\text { Author and } \\
\text { Year of } \\
\text { Publication }\end{array}$ & Title & Country & Methods & Sample & Results \\
\hline $\begin{array}{l}\text { Abdullah, } \\
\text { Waluyo and } \\
\text { Wardani } \\
\text { (2019) }\end{array}$ & $\begin{array}{l}\text { Hard Work } \\
\text { Character } \\
\text { Education in the } \\
\text { Novel Merindu } \\
\text { Baginda Nabi by } \\
\text { Habiburrahman } \\
\text { El-Shirazy }\end{array}$ & Indonesia & Qualitative & - & $\begin{array}{l}\text { Describe some of the } \\
\text { values of character } \\
\text { education of hard work } \\
\text { in the novel longing for } \\
\text { the king's prophet by } \\
\text { Habiburrahman El- } \\
\text { Shirazy. }\end{array}$ \\
\hline $\begin{array}{l}\text { Abdullah, } \\
\text { Hastuti, and } \\
\text { Karmila } \\
(\mathbf{2 0 1 5 )}\end{array}$ & $\begin{array}{l}\text { Lego (bingo } \\
\text { puzzle) games: } \\
\text { character } \\
\text { education-based } \\
\text { educational media } \\
\text { in elementary } \\
\text { school-age } \\
\text { children in } \\
\text { realizing } \\
\text { Indonesia's } \\
\text { Golden } \\
\text { Generation }\end{array}$ & Indonesia & $\begin{array}{l}\text { Qualitative } \\
\text { Descriptive }\end{array}$ & - & $\begin{array}{l}\text { Lego games learning } \\
\text { media were created } \\
\text { with the aim that } \\
\text { students are easy to } \\
\text { apply and get used to } \\
\text { applying the values of } \\
\text { character education, } \\
\text { which has implications } \\
\text { for the formation of } \\
\text { the personality of } \\
\text { students as good } \\
\text { shoots nation. }\end{array}$ \\
\hline $\begin{array}{l}\text { Anggi } \\
(2018)\end{array}$ & $\begin{array}{l}\text { Al-Quran } \\
\text { Perspective } \\
\text { Hadith Character } \\
\text { Education }\end{array}$ & Indonesia & Qualitative & - & $\begin{array}{l}\text { The hadith appeared in } \\
\text { this study contains } \\
\text { human character or } \\
\text { behavior towards God, } \\
\text { self, fellow human } \\
\text { beings, and the } \\
\text { environment. Some } \\
\text { concepts of character } \\
\text { education that can be } \\
\text { revealed from the Quran } \\
\text { and the Hadith are First, } \\
\text { the basis of character } \\
\text { education, Second. The } \\
\text { concept of character } \\
\text { education in Islam. } \\
\text { Third, the stages of } \\
\text { forming character } \\
\text { education. Fourth, the } \\
\text { internalization character } \\
\text { education method. Fifth, }\end{array}$ \\
\hline
\end{tabular}


the role of teachers and parents in character education.

\begin{tabular}{|c|c|c|c|c|}
\hline $\begin{array}{l}\text { Aprilana, } \\
\text { Kristiawan } \\
\text { and } \\
\text { Hafulyon }\end{array}$ & $\begin{array}{l}\text { Madrasah Head } \\
\text { Leadership in } \\
\text { Creating Effective } \\
\text { Learning in } \\
\text { Madrasah } \\
\text { Ibtidaiyyah } \\
\text { Rahmah El } \\
\text { Yunusiyyah } \\
\text { Diniyyah Princess } \\
\text { Padang Panjang }\end{array}$ & Indonesia & Qualitative & $\begin{array}{l}1 \\
\text { Principal }\end{array}$ \\
\hline
\end{tabular}

Effective learning is done to produce good student attitudes and achievements. The principal's leadership looks good because his concern continues to develop teacher and student participation. Headmaster applied 1) technical skills; 2) human skills; and 3) conceptual skills in his leadership.

\begin{tabular}{lllll}
\hline $\begin{array}{l}\text { Aravena } \\
\text { (2019) }\end{array}$ & Destructive & Chile & Qualitative & 207 \\
& Leadership & & research & $(34 \%)$ \\
& Behavior: An & & based on & teachers \\
& Exploratory Study & & interpretive & \\
& in Chile & & phenomena &
\end{tabular}

\begin{tabular}{|c|c|c|c|}
\hline $\begin{array}{l}\text { Azhary, } \\
\text { Handoyo, } \\
\text { and Khafid } \\
(\mathbf{2 0 1 8 )}\end{array}$ & $\begin{array}{l}\text { The } \\
\text { implementation of } \\
\text { integrated } \\
\text { character } \\
\text { education in } \\
\text { policy design at } \\
\text { SD } \\
\text { Muhammadiyah } \\
\text { (Plus) Salatiga }\end{array}$ & Indonesia & Qualitative \\
\hline
\end{tabular}

Leaders who are often labeled as destructive show autocratic leadership, poor communication, inconsistent behavior,

SD Muhammadiyah (Plus) Salatiga has implemented character education that is integrated into school policies, this is evidenced by the inclusion of and poor strategic skills. environmental, religious, autonomous, loving, homeland character values in the vision, mission and school programs. An honest, conscientious, innovative, and independent character has also been integrated into the classroom, this is seen in the Lesson Plans and the media created by the teachers.

\begin{tabular}{llllll}
\hline Brooks \& & Culturally & Philippines & Qualitative & 42 & Explicitly emphasizes \\
\hline
\end{tabular}




\begin{tabular}{|c|c|c|c|c|c|}
\hline $\begin{array}{l}\text { Brooks } \\
(2019)\end{array}$ & $\begin{array}{l}\text { (Ir)relevant school } \\
\text { leadership: } \\
\text { Ethnoreligious } \\
\text { conflict and } \\
\text { school } \\
\text { administration in } \\
\text { the Philippines }\end{array}$ & & & $\begin{array}{l}\text { Principal } \\
\mathrm{S}\end{array}$ & $\begin{array}{l}\text { the importance of } \\
\text { principals' meaningful } \\
\text { preparation and } \\
\text { professional } \\
\text { development programs } \\
\text { that cultivate culturally } \\
\text { relevant leadership skills, } \\
\text { reflective practices, and } \\
\text { intercultural } \\
\text { understanding in ways } \\
\text { that can be applied } \\
\text { locally. }\end{array}$ \\
\hline $\begin{array}{l}\text { Dekawati } \\
(2020)\end{array}$ & $\begin{array}{l}\text { The Principal's } \\
\text { Leadership As } \\
\text { The Effort To } \\
\text { Build Students' } \\
\text { Character }\end{array}$ & Indonesia & Qualitative & $\begin{array}{l}85 \\
\text { Teachers }\end{array}$ & $\begin{array}{l}\text { The principal's } \\
\text { leadership is } \\
\text { an alternative way to } \\
\text { build student character. } \\
\text { Based on the results, the } \\
\text { author suggests that (1) } \\
\text { the principal increases } \\
\text { information disclosure } \\
\text { through communication } \\
\text { by maximizing digital } \\
\text { communication facilities } \\
\text { and hold flag ceremonies } \\
\text { to be delivered } \\
\text { information optimally. } \\
\text { (2) The principal builds } \\
\text { solid teamwork and } \\
\text { participates in social } \\
\text { activities in collaboration } \\
\text { with local communities } \\
\text { in protecting the } \\
\text { environment. }\end{array}$ \\
\hline $\begin{array}{l}\text { Dou, } \\
\text { Devos, and } \\
\text { Valcke } \\
(2017)\end{array}$ & $\begin{array}{l}\text { The relationships } \\
\text { between school } \\
\text { autonomy gap, } \\
\text { principal } \\
\text { leadership, } \\
\text { teachers'job } \\
\text { satisfaction, and } \\
\text { organizational } \\
\text { commitment }\end{array}$ & China & Quantitative & $\begin{array}{l}528 \\
\text { Teachers } \\
\text { and 59 } \\
\text { Principal } \\
\text { s }\end{array}$ & $\begin{array}{l}\text { The significance of } \\
\text { instructional and } \\
\text { transformational } \\
\text { leadership on teacher's } \\
\text { job satisfaction and } \\
\text { organizational } \\
\text { commitment, mediated } \\
\text { by the indirect impacts of } \\
\text { the school climate and } \\
\text { teacher's self-efficacy. } \\
\text { The school autonomy } \\
\text { gap, which is closely } \\
\text { related to the leadership } \\
\text { of the school principal, }\end{array}$ \\
\hline
\end{tabular}




\begin{tabular}{|c|c|c|c|c|c|}
\hline & & & & & $\begin{array}{l}\text { appears as an important } \\
\text { effect. }\end{array}$ \\
\hline $\begin{array}{l}\text { Eisenschmi } \\
\text { dt, } \\
\text { Kuusisto, } \\
\text { Poom- } \\
\text { Valicks, and } \\
\text { Tirri (2019) }\end{array}$ & $\begin{array}{l}\text { Virtues That } \\
\text { Create Purpose } \\
\text { For Ethical } \\
\text { Leadership: } \\
\text { Exemplary } \\
\text { Principals From } \\
\text { Estonia And } \\
\text { Finland }\end{array}$ & Finlandia & Qualitative & - & $\begin{array}{l}\text { In building schools for } \\
\text { future generations, } \\
\text { principals must } \\
\text { demonstrate virtue, } \\
\text { wisdom and knowledge } \\
\text { in creating a long-term } \\
\text { vision for the school. }\end{array}$ \\
\hline $\begin{array}{l}\text { Farida } \\
(2016)\end{array}$ & $\begin{array}{l}\text { Pendidikan } \\
\text { Karakter Dalam } \\
\text { Prespektif Islam }\end{array}$ & Indonesia & Qualitative & - & $\begin{array}{l}\text { The Qur'an very firmly } \\
\text { provides concrete } \\
\text { solutions for us to } \\
\text { develop spiritual, } \\
\text { emotional, and } \\
\text { intellectual awareness } \\
\text { which not only become } \\
\text { theories, but the Qur'an } \\
\text { commands to translate } \\
\text { them into daily life. }\end{array}$ \\
\hline $\begin{array}{l}\text { Ismail } \\
\text { (2018) }\end{array}$ & $\begin{array}{l}\text { Pengembangan } \\
\text { Karakter melalui } \\
\text { Pendidikan } \\
\text { Agama Islam }\end{array}$ & Indonesia & Qualitative & - & $\begin{array}{l}\text { Character development } \\
\text { through Islamic religious } \\
\text { education in Indonesia } \\
\text { and its correlation with } \\
\text { the mental and spiritual } \\
\text { development of the } \\
\text { nation's children. }\end{array}$ \\
\hline $\begin{array}{l}\text { Jamrah } \\
(2017)\end{array}$ & $\begin{array}{l}\text { Shaping Golden } \\
\text { Generation } \\
\text { Through } \\
\text { Character } \\
\text { Education Toward } \\
100 \text { Years } \\
\text { Indonesia }\end{array}$ & Indonesia & Qualitative & - & $\begin{array}{l}\text { The golden generation } \\
\text { must be ready from now } \\
\text { through education. In } \\
\text { addition to building } \\
\text { knowledge competence } \\
\text { (Cognitive) and skills } \\
\text { (psychomotor), balance } \\
\text { is also very important } \\
\text { with building character } \\
\text { (affective). }\end{array}$ \\
\hline $\begin{array}{l}\text { Jones } \\
(\mathbf{2 0 1 5})\end{array}$ & $\begin{array}{l}\text { Contemporary } \\
\text { challenges and } \\
\text { changes: } \\
\text { principals' } \\
\text { leadership } \\
\text { practices in } \\
\text { Malaysia }\end{array}$ & Malaysia & Quantitative & $\begin{array}{l}7 \\
\text { Systems } \\
\text { Leadersh } \\
\text { ip Study }\end{array}$ & $\begin{array}{l}\text { Empirical evidence is } \\
\text { emerging about } \\
\text { principals' leadership } \\
\text { practices and highlights } \\
\text { some of the challenges } \\
\text { associated with new } \\
\text { accountability } \\
\text { expectations and } \\
\text { demands given to actors } \\
\text { in Malaysia. }\end{array}$ \\
\hline Lijuan, & Principal & Hong & cross- & 32 & The various dimensions \\
\hline
\end{tabular}




\begin{tabular}{|c|c|c|c|c|c|}
\hline $\begin{array}{l}\text { Hallinger, } \\
\text { and Ko } \\
(2016)\end{array}$ & $\begin{array}{l}\text { leadership and } \\
\text { school capacity } \\
\text { effects on teacher } \\
\text { learning in Hong } \\
\text { Kong. }\end{array}$ & Kong. & $\begin{array}{l}\text { sectional a } \\
\text { Quantitative } \\
\text { method }\end{array}$ & $\begin{array}{l}\text { elementa } \\
\text { ry } \\
\text { schools }\end{array}$ & $\begin{array}{l}\text { of the leadership of the } \\
\text { principal make a } \\
\text { significant contribution } \\
\text { to the capacity of the } \\
\text { school and the } \\
\text { professional learning of } \\
\text { teachers. The presence of } \\
\text { cooperation, trust, } \\
\text { communication, support } \\
\text { for students, and } \\
\text { alignments, coherence, } \\
\text { and structure in schools } \\
\text { also influence teacher } \\
\text { professional learning. }\end{array}$ \\
\hline $\begin{array}{l}\text { Mahara, } \\
\text { Harun, and } \\
\text { Usman } \\
(2017)\end{array}$ & $\begin{array}{l}\text { Principal's } \\
\text { leadership style in } \\
\text { improving teacher } \\
\text { discipline in } \\
\text { MAN Pegasing, } \\
\text { Central Aceh } \\
\text { district. }\end{array}$ & Indonesia & Qualitative & - & $\begin{array}{l}\text { Research limitations / } \\
\text { implications } \\
\text { (1) MAN Pegasing's } \\
\text { style in Central Aceh } \\
\text { District in improving } \\
\text { teacher discipline is in an } \\
\text { authoritarian and } \\
\text { democratic style (2) } \\
\text { MAN Pegasing's } \\
\text { principal in Central Aceh } \\
\text { District has obstacles in } \\
\text { increasing teacher } \\
\text { discipline in schools. }\end{array}$ \\
\hline $\begin{array}{l}\text { Maryam, } \\
\text { Ummah, } \\
\text { Munjin, } \\
\text { and Faris } \\
(2017)\end{array}$ & $\begin{array}{l}1 \text { Hour Q-Time as } \\
\text { a Preventive } \\
\text { Effort of Juvenile } \\
\text { Delinquencies to } \\
\text { Prepare the } \\
\text { Golden } \\
\text { Generation of } \\
\text { Indonesia } 2045\end{array}$ & Indonesia & Qualitative & - & $\begin{array}{l}\text { Describe the idea of } \\
\text { creating new innovative } \\
\text { programs to improve } \\
\text { family harmony with } \\
\text { character education }\end{array}$ \\
\hline $\begin{array}{l}\text { Murniati } \\
\text { (2018) }\end{array}$ & $\begin{array}{l}\text { Principal's } \\
\text { Leadership in } \\
\text { Improving } \\
\text { Teacher } \\
\text { Professional } \\
\text { Competence at } \\
\text { SD Negeri } 13 \\
\text { Banda Aceh City. }\end{array}$ & Indonesia & ex post facto & $\begin{array}{l}279 \\
\text { students }\end{array}$ & $\begin{array}{l}\text { Teacher professional } \\
\text { Competence and learning } \\
\text { discipline significantly } \\
\text { influence social studies } \\
\text { learning outcomes. } \\
\text { Teachers should always } \\
\text { try to improve their } \\
\text { professional competence } \\
\text { and are expected to } \\
\text { discipline students to } \\
\text { learn well at home and }\end{array}$ \\
\hline
\end{tabular}




\begin{tabular}{|c|c|c|c|c|c|}
\hline & & & & & school. \\
\hline $\begin{array}{l}\text { Murwaning } \\
\text { sih, } \\
\text { Fadhilah, } \\
\text { and Sholeh } \\
(2020)\end{array}$ & $\begin{array}{l}\text { The } \\
\text { Implementation of } \\
\text { Characters' } \\
\text { Values Through } \\
\text { Local Wisdom of } \\
\text { Sadranan in } \\
\text { Elementary } \\
\text { Schools }\end{array}$ & Indonesia & Qualitative & - & $\begin{array}{l}\text { The application of local } \\
\text { wisdom can be achieved } \\
\text { by habituation and } \\
\text { integration } \\
\text { local wisdom values } \\
\text { become class lessons. }\end{array}$ \\
\hline $\begin{array}{l}\text { Quin, } \\
\text { Deries, } \\
\text { Bischoff, } \\
\text { and } \\
\text { Johnson } \\
(2015)\end{array}$ & $\begin{array}{l}\text { Comparison of } \\
\text { Transformational } \\
\text { Leadership } \\
\text { Practices: } \\
\text { Implications for } \\
\text { School Districts } \\
\text { and Principal } \\
\text { Preparation } \\
\text { Programs }\end{array}$ & USA & Qualitative & $\begin{array}{l}92 \\
\text { Teachers }\end{array}$ & $\begin{array}{l}\text { (a) principals in high- } \\
\text { performance schools } \\
\text { more often apply } \\
\text { leadership practices than } \\
\text { principals in low- } \\
\text { performing schools and } \\
\text { (b) inspire a shared } \\
\text { vision and challenge the } \\
\text { process in two practices } \\
\text { that have the greatest } \\
\text { impact on student } \\
\text { achievement. }\end{array}$ \\
\hline $\begin{array}{l}\text { Rina, } \\
\text { Murtini, } \\
\text { and } \\
\text { Indriayu } \\
\text { (2018) }\end{array}$ & $\begin{array}{l}\text { Establishment of } \\
\text { entrepreneurial } \\
\text { character in the } \\
\text { foundation based } \\
\text { school system } \\
\text { through project- } \\
\text { based learning }\end{array}$ & Indonesia & Qualitative & - & $\begin{array}{l}\text { Show those learning } \\
\text { activities based on } \\
\text { activities on the project } \\
\text { form entrepreneur } \\
\text { according to the level of } \\
\text { entrepreneurship of } \\
\text { students' education level. } \\
\text { The character of } \\
\text { elementary school } \\
\text { students is independent, } \\
\text { creative, honest, and } \\
\text { discs }\end{array}$ \\
\hline $\begin{array}{l}\text { Septigaman } \\
\text { dari and } \\
\text { Ardipal } \\
\text { (2019) }\end{array}$ & $\begin{array}{l}\text { Implementing } \\
\text { Character Values } \\
\text { through Music } \\
\text { Learning in Class } \\
\text { V SDN 04 PPA. }\end{array}$ & Indonesia & Qualitative & $\begin{array}{l}\text { Grade } 5 \\
\text { Students }\end{array}$ & $\begin{array}{l}\text { Show how the } \\
\text { characteristics of } \\
\text { planning and creativity in } \\
\text { instilling character } \\
\text { values through music } \\
\text { learning in class V SDN } \\
\text { 04 PPA TanjungHarapan } \\
\text { District, Solok City }\end{array}$ \\
\hline $\begin{array}{l}\text { Setiyati } \\
(2014)\end{array}$ & $\begin{array}{l}\text { The influence of } \\
\text { the principal's } \\
\text { leadership, work } \\
\text { motivation, and } \\
\text { school culture on } \\
\text { teacher } \\
\text { performance. }\end{array}$ & Indonesia & Quantitative & $\begin{array}{l}753 \\
\text { Teachers }\end{array}$ & $\begin{array}{l}\text { 1) There is a positive and } \\
\text { very significant influence } \\
\text { from the principal's } \\
\text { leadership, work } \\
\text { motivation, and school } \\
\text { culture on teacher } \\
\text { performance with a }\end{array}$ \\
\hline
\end{tabular}


percentage of $42.2 \%$.

(2) There is a positive and very significant influence on the principal's leadership on the teacher's performance with a percentage of $18.22 \%$ (3) There is a positive and very significant influence of work motivation on teacher performance with a percentage of $13.03 \%$

(4) There is a positive and very significant influence of school culture on teacher performance with a percentage of $10.94 \%$.

Simanjunta The Importance k (2019) of Implementing a Curriculum Based on Strengthening

Character

Education for the

Creation of the

Indonesian

Golden

Generation in

2045

Indonesia Qualitative

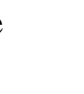

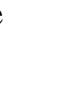


includes strengthening values people, become good creatures from God as in Faith, and can do good deeds and moral actions in society.

\begin{tabular}{|c|c|c|c|c|}
\hline $\begin{array}{l}\text { Tingle, } \\
\text { Corrales, } \\
\text { and Peters } \\
(2019)\end{array}$ & $\begin{array}{l}\text { Leadership } \\
\text { development } \\
\text { programs: } \\
\text { investing in } \\
\text { school principals }\end{array}$ & USA & Quantitative & $\begin{array}{l}59 \\
\text { Principal } \\
\mathrm{s}\end{array}$ \\
\hline
\end{tabular}

Principals consider that

training activities related to human resources, executive leadership, school culture, and strategic operations, have a "high" influence on their effectiveness as school leaders.

\begin{tabular}{|c|c|c|c|c|c|}
\hline $\begin{array}{l}\text { Truong, } \\
\text { Hallinger, } \\
\text { and Sanga } \\
(2017)\end{array}$ & $\begin{array}{l}\text { Confucian Values } \\
\text { and } \\
\text { SchoolLeadership } \\
\text { in Vietnam: } \\
\text { Exploring the } \\
\text { Influence } \\
\text { ofCulture on } \\
\text { Principal } \\
\text { DecisionMaking }\end{array}$ & Vietnam & Qualitative & 3 schools & $\begin{array}{l}\text { In Vietnam, school } \\
\text { leadership must adopt the } \\
\text { values of the 'indigenous } \\
\text { perspective' to be a good } \\
\text { leader for schools. }\end{array}$ \\
\hline $\begin{array}{l}\text { Angela } \\
\text { Urick } \\
(\mathbf{2 0 1 6 )}\end{array}$ & $\begin{array}{l}\text { Examining US } \\
\text { Principalperceptio } \\
\text { n Of Multiple } \\
\text { Leadershipstyles } \\
\text { Used To Practice } \\
\text { Sharedinstruction } \\
\text { al Leadership }\end{array}$ & USA & Quantitative & $\begin{array}{l}8,524 \\
\text { Principal } \\
\mathrm{s}\end{array}$ & $\begin{array}{l}\text { Appropriate } \\
\text { improvement in } \\
\text { leadership style practice } \\
\text { by shared instructional } \\
\text { leadership may not be } \\
\text { defined by categorized } \\
\text { needs. }\end{array}$ \\
\hline $\begin{array}{l}\text { Wardoyo } \\
\text { (2015) }\end{array}$ & $\begin{array}{l}\text { Character } \\
\text { Education: } \\
\text { Building the } \\
\text { National Identity } \\
\text { Towards a } \\
\text { Religious } 2045 \\
\text { Gold Generation }\end{array}$ & Indonesia & Qualitative & - & $\begin{array}{l}\text { All elements of society } \\
\text { must play an active role } \\
\text { in achieving these goals } \\
\text { through character } \\
\text { education to achieve the } \\
\text { golden generation of } \\
2045 \text { which is religious. }\end{array}$ \\
\hline $\begin{array}{l}\text { Widodo } \\
\text { (2019) }\end{array}$ & $\begin{array}{l}\text { Strengthening } \\
\text { character } \\
\text { education at SD } \\
\text { Muhammadiyah } \\
\text { Macanan Sleman } \\
\text { Yogyakarta }\end{array}$ & Indonesia & Qualitative & $\begin{array}{l}1 \\
\text { Principal, } \\
6 \\
\text { teachers } \\
\text { dan } 6 \\
\text { students }\end{array}$ & $\begin{array}{l}\text { Strengthening religious } \\
\text { character education is } \\
\text { carried out integrated } \\
\text { with several subjects } \\
\text { such as Islam, al-Islam, } \\
\text { Arabic, worship } \\
\text { practices, and } \\
\text { Muhammadiyah. } \\
\text { Strengthening } \\
\text { nationalism character }\end{array}$ \\
\hline
\end{tabular}


education through routine flag ceremony activities every Monday, and batik extracurricular activities. Strengthening independent character education, namely students making class rules (golden class).

Strengthening mutual education character education, that is, students help each other in doing each activity. Strengthening character integrity education, that is, students are responsible for doing learning and in activities outside the classroom.

Source: Data Adapted from various publication mentioned

This section reports the main findings of the article being reviewed. The analysis shows that most of the articles focus on the Principal's Leadership, the Character of the Indonesian Gold Generation. The articles that have been reviewed are research conducted in several countries. Based on the articles reviewed, there are various ways of collecting data related to school principal leadership and the formation of the character of the golden generation of Indonesia. The research method used from article to article. The most commonly used method is by using interviews and observations used by [24], [18], [22], [25], [5], [31], [4].

Research on the principal's leadership in shaping the character of the golden generation has been carried out in Indonesia and various organizations in various countries. Table 1 shows that research has been carried out in schools, universities, and schools. The results of the majority of studies indicate that the leadership of the principal is an alternative way to build an integrated character in school policy, by incorporating the values of environmental, religious, autonomous, autonomous, loving character of the motherland, courtesy and courtesy in the vision, mission and programs school. To create a golden generation of Indonesia, all elements of society must play a role in supporting every government program to improve the quality of Indonesian by enhancing character education, so it becomes a comprehensive curriculum for the creation of a golden generation of Indonesia that is a strong national successor based on religious Pancasila. 


\section{Conclusion}

The results based on the literature review, it can be concluded that principal leadership has a positive and significant effect on character education in various countries including Indonesia. This shows that the principal's leadership will influence the character of the golden generation. The conclusions from this study were generally obtained when the authors considered all the study reviews, which showed that the principal's leadership was very important for shaping the students' character in preparing for Indonesia's golden generation. The broad conclusion is that when the writer considers all the study reviews of the principal's leadership in shaping the character of the golden generation in Indonesia, it shows that the leadership of the principal is very important for the formation of student character in preparing for the golden generation of Indonesia. This means that the leadership of the principal plays an important role and has a big impact in determining the character formation of Indonesia's golden generation.

\section{Limitation and Study Forward}

As with research, this review has limitations. First, the articles were reviewed more in English so other studies were not reviewed because of limitations in the context of some countries. Second, dissertations and theses are not discussed in this article because they can cause publication bias in the results. Third, the scope of the article being reviewed is still limited. The researchers hope there will be further research on the Principal's Leadership, Character of Indonesia's Golden Generation.

Acknowledgment. The authors thank the Faculty of Teacher Training and Education, University of Lampung, Indonesia, for the opportunity to have given to the authors to conduct this research and support this research by enabling researchers to access information needs.

\section{REFERENCES}

[1] Septigamandari, S., \& Ardipal, A. (2019). Penanaman Nilai Karakter Melalui Pembelajaran Musik Di Kelas V Sdn 04 Ppa. Jurnal Basicedu, 3(2). doi:10.31004/basicedu.v3i2.178

[2] Rina, L., Murtini, W., \& Indriayu, M. (2018). Establishment of entrepreneurial character in the foundation based school system through project-based learning. International Journal of Educational Research Review, 3(4). doi:10.24331/ijere.455049

[3] Abdullah, M. Y., Hastuti, W., \& Karmila, A. (2015). Lego (puzzle bingo) games: media edukatif berbasis pendidikan karakter pada anak usia sekolah dasar dalam mewujudkan generasi indonesia emas. PENA: Jurnal Penelitian Dan Penalaran, 2(1), 296-307.

[4] Widodo, H. (2019). Penguatan pendidikan karakter di SD Muhammadiyah macanan sleman Yogyakarta. Lentera Pendidikan: Jurnal Ilmu Tarbiyah dan Keguruan, 22(1). Retrieved from http://journal.uinalauddin.ac.id/index.php/lentera_pendidikan/article/viewFile/7260/6408

[5] Simanjuntak, R. (2019). Pentingnya Penerapan Kurikulum Berbasis Penguatan Pendidikan Karakter bagi Terciptanya Generasi Emas Indonesia Tahun 2045. JURNAL TERUNA BHAKTI, 1(2). Retrieved from http://stakterunabhakti.ac.id/ejournal/index.php/teruna/article/viewFile/17/17 
[6] Truong, T. D., Hallinger, P., \& Sanga, K. (2017). Confucian values and school leadership in Vietnam: Exploring the influence of culture on principal decision making. Educational Management Administration \& Leadership, 45(1). doi:10.1177/1741143215607877

[7] Eisenschmidt, E., Kuusisto, E., Poom-Valickis, K., \& Tirri, K. (2019). Virtues that create a purpose for ethical leadership: Exemplary principals from Estonia and Finland. Journal of Beliefs \& Values. doi:10.1080/13617672.2019.1618152

[8] Mahara, R., Harun, C. Z., \& Usman, N. (2017). Gaya kepemimpinan kepala sekolah dalam meningkatkan kedisiplinan guru pada man pegasing kebupaten aceh tengah. Jurnal Administrasi Pendidikan: Program Pascasarjana Unsyiah, 5(1).

[9] Setiyati, S. (2014). Pengaruh kepemimpinan kepala sekolah, motivasi Kerja, dan budaya sekolah terhadap kinerja guru. Jurnal Pendidikan Teknologi dan Kejuruan, 22(2), 200206. doi:10.21831/jptk.v22i2.8931

[10] Quin, J., Deris, A., Bischoff, G., \& Johnson, J. T. (2015). Comparison of Transformational Leadership Practices: Implications for School Districts and Principal Preparation Programs. Journal of Leadership Education, 14(3). doi:1012806/V14/I3/R5

[11] Aprilana, E. R., Kristiawan, M., \& Hafulyon, H. (2017). Kepemimpinan Kepala Madrasah dalam Mewujudkan Pembelajaran Efektif di Madrasah Ibtidaiyyah Rahmah El Yunusiyyah Diniyyah Puteri Padang Panjang. ELEMENTARY: Islamic Teacher Journal, 4(1). $\quad$ Retrieved from http://journal.stainkudus.ac.id/index.php/elementary/article/viewFile/1975/pdf

[12] Urick, A. (2016). Examining US principal perception of multiple leadership styles used to practice shared instructional leadership. Journal of Educational Administration, 54(2). doi:10.1108/JEA-07-2014-0088

[13] Jones, M., Adams, D., Hwee Joo, M. T., Muniandy, V., Perera, C. J., \& Harris, A. (2015). Contemporary challenges and changes: principals' leadership practices in Malaysia. Asia Pacific Journal of Education, 35(3). doi:10.1080/02188791.2015.1056591

[14] Murniati, A. (2018). Kepemimpinan kepala sekolah dalam meningkatkan kompetensi profesional guru pada sd negeri 13 kota banda aceh. Jurnal Administrasi Pendidikan: Program Pascasarjana Unsyiah, 6(4). Retrieved from http://www.jurnal.unsyiah.ac.id/JAP/article/download/13152/10055

[15] Lijuan, L., Hallinger, P., \& Ko, J. (2016). Principal leadership and school capacity effects on teacher learning in Hong Kong. International Journal of Educational Management, 30(1). doi:10.1108/IJEM-03-2014-0035

[16] Aravena, F. (2019). Destructive leadership behavior: An exploratory study in Chile. Leadership and Policy in Schools, 18(1). DOI:10.1080/15700763.2017.1384501

[17] Brooks, M. C., \& Brooks, J. S. (2019). Culturally (Ir) relevant school leadership: Ethnoreligious conflict and school administration in the Philippines. International Journal of Leadership in Education, 22(1). doi:10.1080/13603124.2018.1503819

[18] Dekawati, I. (2020). The Principal's Leadership As The Effort To Build Students'character. International Journal of Educational Management and Innovation, $1(2)$.

[19] Leithwood, K., Harris, A., \& Hopkins, D. (2019). Seven strong claims about successful school leadership revisited. School Leadership \& Management. doi:10.1080/13632434.2019.1596077

[20] Tingle, E., Corrales, A., \& Peters, M. L. (2019). Leadership development programs: Investing in school principals. Educational Studies, 45(1). doi:10.1080/03055698.2017.1382332 
[21] Dou, D., Devos, G., \& Valcke, M. (2017). The relationships between the school autonomy gap, principal leadership, teachers' job satisfaction, and organizational commitment. Educational Management Administration \& Leadership, 45(6), 959-977. doi:10.1177/1741143216653975

[22] Jamrah, A. (2017). Shaping the Golden Generation through Character Education toward 100 Years Indonesia. Proceeding IAIN Batusangkar, 1(2).

[23] Supriyono, S. (2016). Developing Character Education Regarding Islamic Perspective: A Conceptual Review. JARES (Journal of Academic Research and Sciences), 1(1).

[24] Azhary, L., Handoyo, E., \& Khafid, M. (2018). The implementation of integrated character education in policy design at SD Muhammadiyah (plus) Salatiga. Journal of Primary Education, 7(2), 172-178. doi:10.15294/jpe.v7i2.23522

[25] Maryam, S., Ummah, F., Munjin, A., \& Faris, A. (2017). 1 Hour Q-Time as a Preventive Effort of Juvenile Delinquencies to Prepare the Golden Generation of Indonesia 2045. Paper presented at the International Conference on Learning Innovation (ICLI 2017).

[26] Murwaningsih, T., Fadhilah, S. S., \& Sholeh, A. R. (2020). The Implementation of Characters' Values Through Local Wisdom of Sadranan in Elementary Schools. International Journal of Multicultural and Multireligious Understanding, 7(1).

[27] Farida, S. (2016). Pendidikan karakter dalam prespektif islam. KABILAH: Journal of Social Community, 1(1). Retrieved from http://ejournal.kopertais4.or.id/madura/index.php/kabilah/article/download/1724/ $1273 /$

[28] Anggi, F. (2018). Pendidikan Karakter Prespektif Al-Quran Hadits. TA'LIM: Jurnal Studi Pendidikan Islam, 1(2). doi:10.29062/ta'lim.v1i2.952

[29] Abdullah, A. R., Waluyo, H. J., \& Wardani, N. E. (2019). Pendidikan Karakter Kerja Keras Dalam Novel Merindu Baginda Nabi Karya Habiburrahman El-Shirazy. Paper presented at the Prosiding Seminar Nasional "Inovasi Pembelajaran Bahasa Indonesia di Era Revolusi Industri 4.0".

[30] Ismail, F. (2018). Pengembangan Karakter melalui Pendidikan Agama Islam. Jurnal Ilmiah Iqra', 7(2). doi:10.30984/jii.v7i2.608

[31] Wardoyo, S. M. (2015). Pendidikan Karakter: Membangun Jatidiri Bangsa Menuju Generasi Emas 2045 Yang Religius. TADRIS: Jurnal Pendidikan Islam, 10(1). Retrieved from http://ejournal.stainpamekasan.ac.id/index.php/tadris/article/viewFile/640/600 